\title{
Influence of Wind Direction on the Level of Trace Metals in Plants Collected around a Quarry Site in South Africa
}

\author{
Idris Olawale Raimi ${ }^{1 *}$, Bukola Fisayo Komolafe ${ }^{1}$, Oludare Oladipo Agboola ${ }^{2}$, \\ Liziwe Lizbeth Mugivhisa ${ }^{1}$, Joshua Oluwole Olowoyo ${ }^{1}$ \\ ${ }^{1}$ Department of Biology, Sefako Makgatho Health Sciences University, Medunsa, Republic of South Africa \\ ${ }^{2}$ Plant Ecology Unit, Botany Department, University of Lagos, Akoka, Nigeria
}

Received: 18 June 2018

Accepted: 9 September 2018

\begin{abstract}
Industrialization has resulted in the release of pollutants, especially trace metals, to the environment, which adversely affects the ecosystem. The present study investigated the influence of wind direction on the level of trace metals deposited on vegetation around the quarry site. Three plants common to the four cardinals of the quarry site, precisely 10 meters away, were collected and transported to a laboratory, where further analyses were carried out to determine the trace metal contents in the air-dried unwashed plants. The plants collected from the southwest direction, which represents the position of the stack that emits smoke from the quarry site, recording the highest trace metal concentration. The result of the plant analysis for trace metal concentration showed that Lantana camara among the three plants bio-accumulated most of the trace metals from the quarry site and other adjoining environment. The levels of trace metals from the plants exceeded the acceptable limits for human and livestock consumption. The study therefore concluded that wind direction and the position of the stack played a significant role in the amount of trace metals around the quarry site.
\end{abstract}

Keywords: Datura stramonium, Lantana camara, Pannicum maximum, trace metals, wind direction

\section{Introduction}

Over the past two centuries mining has been largely responsible for the improvement of the socioeconomic landscape of South Africa by growing the gross domestic product (GDP), boosting state revenue, foreign direct investment and generating employment $[1,2]$. Despite the economic importance of mining to

*e-mail: rimiidris@yahoo.com any nation, the consequences of its activities are borne directly by the ever-increasing populations and societies around the mining areas [3].

Quarrying activity is a necessity that provides much of the materials used in traditional hard flooring, such as granite, limestone, marble, sandstone, slate and even ceramic tiles [4]. Quarrying activities such as rock breaking, grinding, and kiln operations are the primary sources of airborne pollutants (trace metals, particulate matters and other pollutants), which are often dispersed by wind to the surroundings and impact biotic and 
abiotic ecosystem functionality [5]. Blasting of rocks with explosives to extract materials for processing leads to the release of several environmental pollutants [4], including trace metals, particulate matter (PM), and compounds such as carbon monoxide (CO), nitrogen dioxide $\left(\mathrm{NO}_{2}\right)$, sulphur dioxide $\left(\mathrm{SO}_{2}\right)$, and ozone $\left(\mathrm{O}_{3}\right)$, which may threaten plant biodiversity and result in health-related problems and habitat destruction, among others $[4,6]$. Quarrying activity has also been reported as the greatest suspected source of particulate matter and trace metals, which are often dispersed by wind to the surroundings and impacts on human health living within the vicinity of the quarry site $[7,8]$.

High concentrations of trace metals pose a great threat to human health and general ecosystems due to their persistence, inherent toxicity, consequent bioaccumulation and biomagnification in the food chain [7, 9-13]. A very high degree of respiratory morbidity is associated with the quarrying industry in humans [14], while in plants the blockage of stomata hinders photosynthesis around quarrying sites [15]. Dust and other pollutants from industrial and other sources not only deteriorate the ambient air quality, but also pose a serious health risk to people - particularly those suffering from respiratory and cardiovascular diseases $[16,17]$. Studies have attributed abnormal vegetative growth, imbalanced lipid and ionic tissues composition, and increases in foliar temperature [18] on the harboring of trace metals by plants. Dust deposition may also lead to reduced photosynthesis; increased incidence of plant pest and diseases; and effects on human health through the food chain [15]. Pollutants adversely hinder plant growth by altering the photosynthesis rate, pedicle length, biochemical composition, seed germination and leaf stomata [19].

South Africa's history of plant use for food and medicine has spanned through the ages, and a large percentage of the population scavenges plants as foods and medicine available anywhere [20]. Therefore, it is necessary to study the impacts of the quarry deposits on the plants to determine their suitability for consumption by herbivores on free-ranging pasteurization and even some medicinal plants that could be scavenged for health benefits.

There are several studies globally on the distribution and concentration of airborne pollutants such as trace metals in aquatic and terrestrial ecosystems, but few studies have enunciated the impact of wind direction as a dispersal mechanism that could increase the levels of trace metals around the vicinity of quarrying sites in South Africa. There are several studies on the impacts of industrial activities through the release of toxic trace metals on vegetation and human health [7]. Human ingestion of trace metals unknowingly or indirectly from vegetables, meat and dairy consumption, and even medicinal plants poses a great risk on human health and survival [21]. The present study investigated the impact of wind direction in depositing trace metals as pollutants on plants in the environment around a quarry site in Pretoria North, South Africa with a view to establishing its impact on trace metals accumulation in plants collected around it from four different directions, namely northeast, northwest, southeast and southwest of the quarry site.

\section{Methodology}

\section{Study Area and Sample Collection}

The study was carried out in Pretoria North, South Africa between March and July, 2017. Reconnaissance visit was done around the quarry site to identify three different plants with economic and domestic importance common to the four cardinals of the quarry site. The coordinates of the study site are $25.6776^{\circ} \mathrm{S}, 28.1766^{\circ} \mathrm{E}$. Three common plants (Lantana camara, Pannicum maximum, and Datura stramonium) were identified, and five cuttings of the three plants (Lantana camara, Pannicum maximum, and Datura stramonium) were collected randomly from four different cardinals, namely northeast (NE), northwest (NW), southeast (SE) and southwest (SW) of the quarry site. Each direction is about $10 \mathrm{~m}$ from the stack that emits smoke from the quarry site where major crushing activities take place. Samples were collected using secateurs in separate polyethylene bags and transported to the laboratory, where they were correctly identified by a Botanist in the Department of Biology of Sefako Makgatho Health Sciences University, South Africa. After proper identification, the plants were air-dried and bulked.

\section{Sample Digestion}

The collected plants were air-dried until all moisture was completely eliminated. Bulked air-dried unwashed plant samples were ground mechanically using a mortar and a pestle to produce fine powder. Then $0.5 \mathrm{~g}$ of sample was weighed into a beaker. A mixture of $3 \mathrm{ml}$ concentrated $\mathrm{HNO}_{3}, 5 \mathrm{ml} \mathrm{HCIO}_{4}$ and $4 \mathrm{ml} \mathrm{H}_{2} \mathrm{O}_{2}$ was added to the sample, and it was placed on a hot plate for about 7 minutes until a clear solution was obtained. The digested sample was allowed to cool and then filtered into a $50 \mathrm{ml}$ flask using Whatman filter paper. Distilled water was added to make volume.

A blank was prepared similarly but without the ground plant sample for the purpose of quality assurance and quality control. Spiked samples were also prepared. The resulting solutions were then analyzed for trace metals contents in five replicates using ICP-OES in order to determine the concentrations of trace metals in the digested unwashed plant samples.

Certified reference material by the National Institute of Standard and Technology (NIST 1515 Apple Leaves) was also used to validate the method for the purpose of quality assurance.

The data obtained for the trace metals were all subjected to analysis of variance (ANOVA) using SPSS 
23.0 for windows. Means were separated using Duncan's multiple range tests at $\mathrm{p}<0.05$.

\section{Results}

The concentration of Mercury $(\mathrm{Hg})$ in all three plants ranged from $60.3 \pm 4.11 \mathrm{mg} / \mathrm{kg}$ d.m. to $158.7 \pm 37.29 \mathrm{mg} / \mathrm{kg}$ d.m (Table 1), and the highest concentration of $\mathrm{Hg}$ was recorded in Datura stramonium $158.7 \pm 37.29 \mathrm{mg} / \mathrm{kg} \mathrm{d.m}$. in the southwest direction of the site (Table 1). Mercury recorded the lowest concentration of $60.3 \pm 4.11 \mathrm{mg} / \mathrm{kg} \mathrm{d}$.m. in the northwest direction of Lantana camara (Table 1).

At the southwest direction of the study site, the concentrations of trace metals, including $\mathrm{Ni}, \mathrm{Cu}, \mathrm{Zn}$, $\mathrm{Cd}, \mathrm{Cr}, \mathrm{Hg}, \mathrm{Fe}$, and $\mathrm{Mn}$, were significantly higher (232.3 mg/kg d.m, $148.3 \mathrm{mg} / \mathrm{kg}$ d.m, $134.3 \mathrm{mg} / \mathrm{kg}$ d.m, $2925 \mathrm{mg} / \mathrm{kg}$ d.m,, $158.7 \mathrm{mg} / \mathrm{kg}$ d.m,, $283 \mathrm{mg} / \mathrm{kg}$ d.m, $136.7 \mathrm{mg} / \mathrm{kg} \mathrm{d.m)} \mathrm{in} \mathrm{D.} \mathrm{stramonium.} \mathrm{The} \mathrm{higher}$ concentration of Copper $(\mathrm{Cu})$ was recorded in $P$. maximum northwest of the site (Table 1).

The concentration of $\mathrm{Cu}$ ranged from $67.5 \mathrm{mg} / \mathrm{kg}$ d.m. in L. camara at the northwest direction to $1045 \mathrm{mg} / \mathrm{kg}$ d.m in $P$. maximum at the northwest direction (Table 1). In the southwest direction, $D$. stramonium has the higher concentration of $\mathrm{Cu}$ (153.3 mg/kg d.m.).

The concentrations of $\mathrm{Cd}$ and $\mathrm{Mn}$ were highest in all three plants to the southwest, with the exception of $P$. maximum, where it was highest at 123 . At the southwest direction of the study site, the concentrations of the trace metals including $\mathrm{Ni}, \mathrm{Cu}, \mathrm{Zn}, \mathrm{Cd}, \mathrm{Cr}, \mathrm{Hg}$, $\mathrm{Fe}$, and $\mathrm{Mn}$ were significantly higher $(232.3 \mathrm{mg} / \mathrm{kg}$ d.m, $148.3 \mathrm{mg} / \mathrm{kg}$ d.m,, $134.3 \mathrm{mg} / \mathrm{kg}$ d.m,, $2925 \mathrm{mg} / \mathrm{kg}$ d.m,, $158.7 \mathrm{mg} / \mathrm{kg}$ d.m,, $283 \mathrm{mg} / \mathrm{kg}$ d.m,, $136.7 \mathrm{mg} / \mathrm{kg} \mathrm{d.m)} \mathrm{in}$ D. stramonium.

Higher concentrations of $\mathrm{Cu}$ and $\mathrm{Mn}$ were recorded in $P$. maximum to the northwest $(1045 \mathrm{mg} / \mathrm{kg} \mathrm{d} . \mathrm{m})$ and northeast $(178.51 \mathrm{mg} / \mathrm{kg} \mathrm{d.m})$ of the site, respectively (Table 1).

The highest concentration of Fe was recorded to the southwest for all three plants; it ranged from $989 \mathrm{mg} / \mathrm{kg}$ d.m. northeast of Lantana camara to $2925 \mathrm{mg} / \mathrm{kg}$ d.m. southwest of Datura stramonium (Table 1).

The concentration of Zinc (Zn) was highest in the southwest for all the plants except in Lantana camara, where the highest was recorded at $186 \pm 54.37 \mathrm{mg} / \mathrm{kg}$ d.m. to the northeast (Table 1).

Generally, the concentrations of trace metals from this study are in the order $\mathrm{Fe}<\mathrm{Cu}<\mathrm{Mn}<\mathrm{Zn}<\mathrm{Hg}<$ $\mathrm{Cr}<\mathrm{Ni}<\mathrm{Cd}$ (Table 1). From the three plants collected from the study sites, the concentrations of all trace metals exceeded the acceptable limit set by the World Health Organization (WHO). The permissible limit set by WHO for Cd in plants is $0.03 \mathrm{mg} / \mathrm{l}, \mathrm{Cr}-0.05 \mathrm{mg} / \mathrm{kg}$ d.m, $\mathrm{Zn}-3.00 \mathrm{mg} / \mathrm{kg}$ d.m, $\mathrm{Hg}-0.5 \mathrm{mg} / \mathrm{kg}$ d.m, $\mathrm{Mn}-0.50 \mathrm{mg} / \mathrm{kg}$ d.m,, $\mathrm{Ni}-0.02 \mathrm{mg} / \mathrm{kg}$ d.m, $\mathrm{Fe}-63.55 \mathrm{mg} / \mathrm{kg}$ d.m. and $\mathrm{Cu}-1.89 \mathrm{mg} / \mathrm{kg}$ d.m [22].

\section{$\operatorname{Iron}(\mathrm{Fe})$}

There is s significant difference $(\mathrm{p}<0.05)$ in $\mathrm{Fe}$ content between L. camara and D. stramonium in all wind directions of the site (Fig. 1). There is significant difference $(p<0.05)$ among the three plants in the northwest and southeast directions (Fig. 1). Datura stramonium, however, is significantly different $(\mathrm{p}<0.05)$ from the other two plants in all the directions (northeast, northwest, southeast and southwest).

\section{Cadmium $(\mathrm{Cd})$}

There is no significant difference between $L$. camara and $P$. maximum in the northeast, northwest and southwest direction for $\mathrm{Cd}$ concentrations (Fig. 2). Datura stramonium, however, is significantly different $(\mathrm{p}<0.05)$ from the other two plants $(P$. maximum and L. camara) in the northeast (Fig. 2). The concentration of $\mathrm{Cd}$ in $P$. maximum is significantly different $(\mathrm{p}<0.05)$ from the other two plants in the southeast (Fig. 2). There is no significant difference in $\mathrm{Cd}$ concentration in all three plants to the northwest and southwest direction of the study sites (Fig. 2).

\section{Chromium (Cr)}

There is no significant difference in $\mathrm{Cr}$ concentration between L. camara and P. maximum at the northeast and the southwest direction of the study site. However, there is significant difference $(\mathrm{p}<0.05)$ between $P$. maximum and the other two plants at the southeast direction of the study site (Fig. 3). No significant difference is observed in $\mathrm{Cr}$ concentration among the three plants in the northwest direction of the study sites (Fig. 3).

\section{Copper $(\mathrm{Cu})$}

There is a significant difference $(\mathrm{p}<0.05)$ in $\mathrm{Cu}$ concentration between $P$. maximum and the other two plants (L. camara and D. stramonium) in the northwest direction of the study site (Fig. 4). There is no significant difference in the concentration of $\mathrm{Cu}$ among the plants in the southwest direction of the study site (Fig. 4). Furthermore, there is no significant difference between L. camara and $P$. maximum for $\mathrm{Cu}$ concentration in the northeast, southeast and southwest directions of the study site (Fig. 4). In the southeast direction there is a significant difference $(\mathrm{p}<0.05)$ in $\mathrm{Cu}$ concentration between $D$. stramonium and the other two plants ( $L$. camara and P. maximum)

\section{Zinc (Zn)}

There is no significant difference in the concentration of $\mathrm{Zn}$ among the three plants at the northeast and southwest direction of the study site (Fig. 5). A significant difference $(p<0.05)$ was observed in $\mathrm{Zn}$ concentration among all three plants 


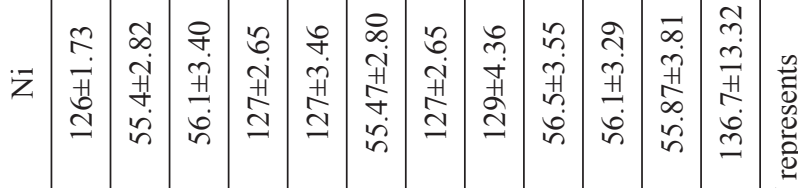

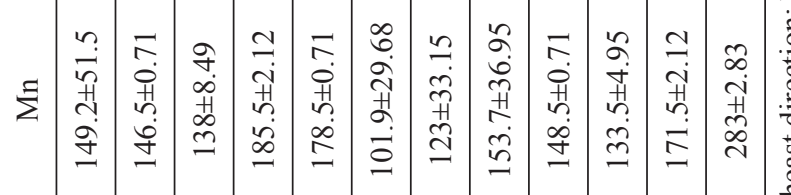

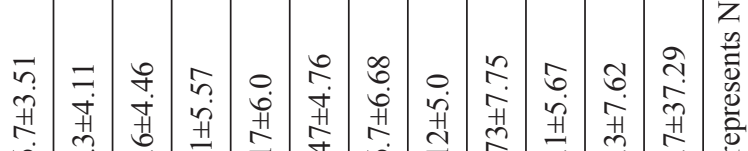

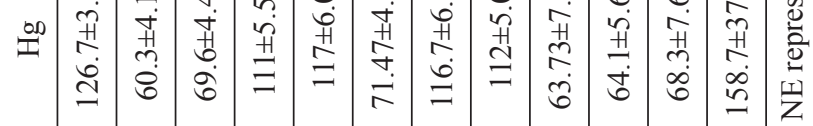

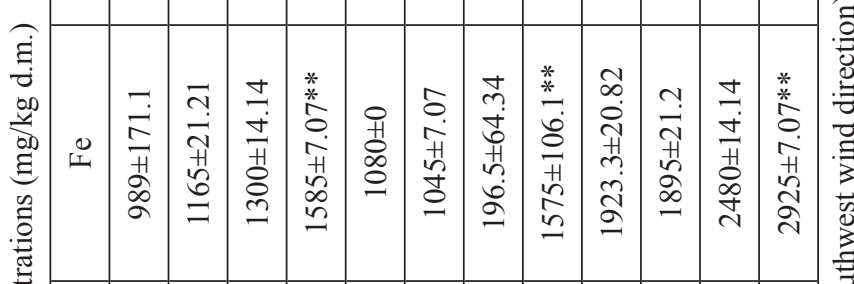

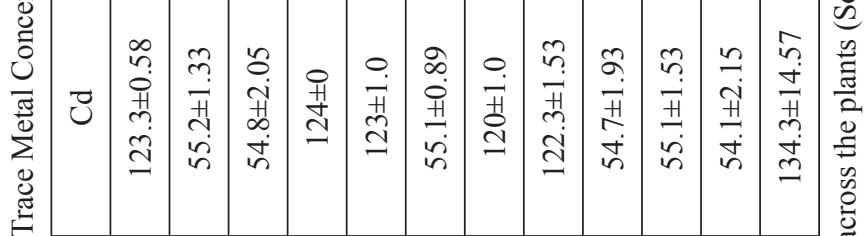

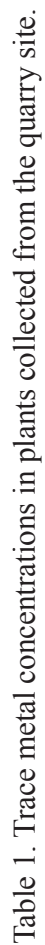

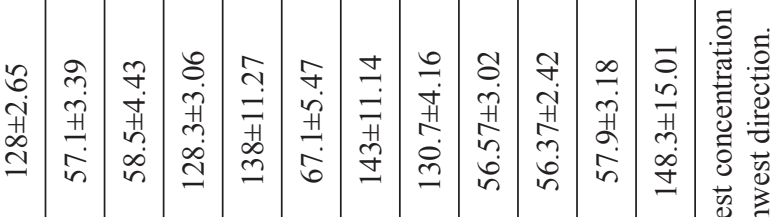

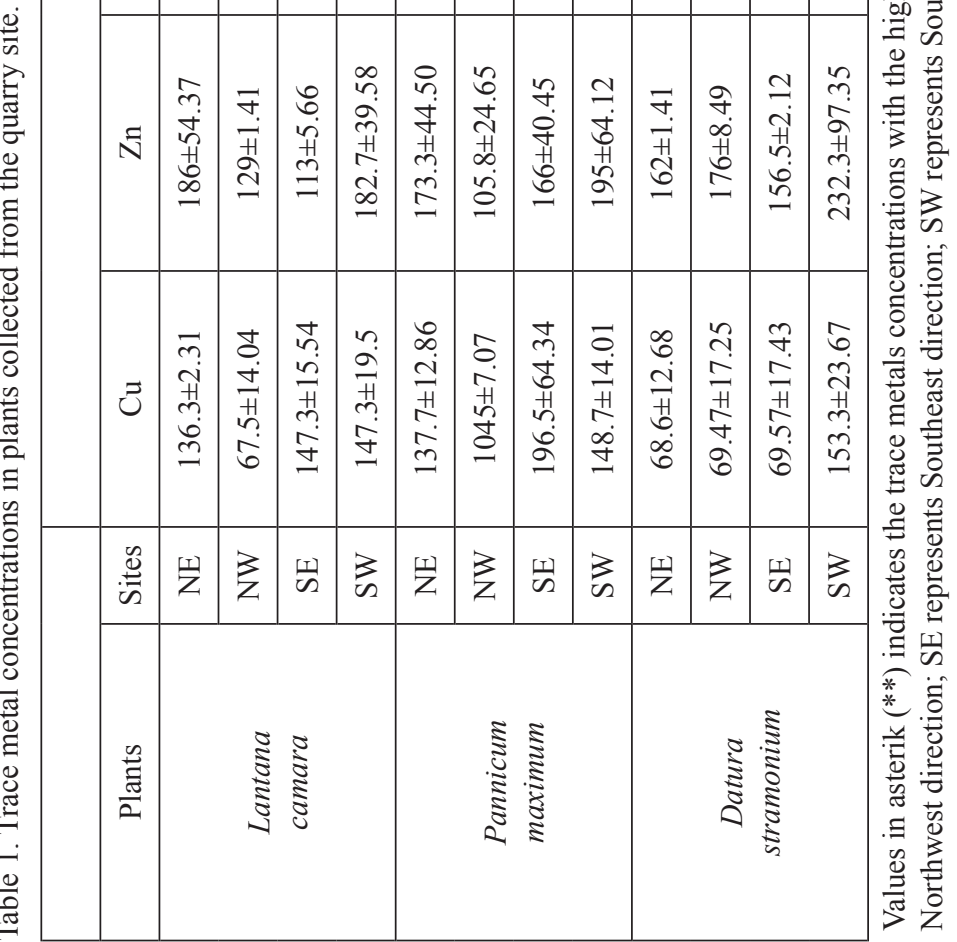




$$
\text { Irone (Fe) }
$$

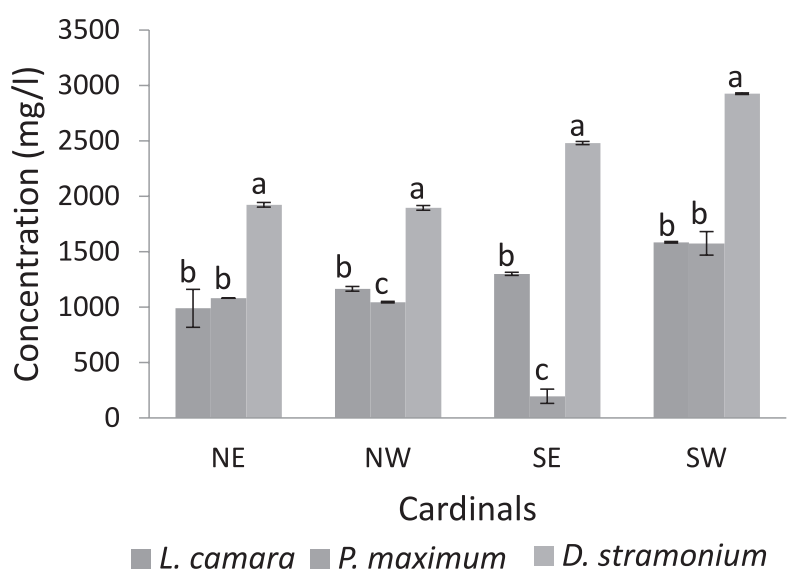

Fig. 1. Iron concentrations in plants collected from across the directions.

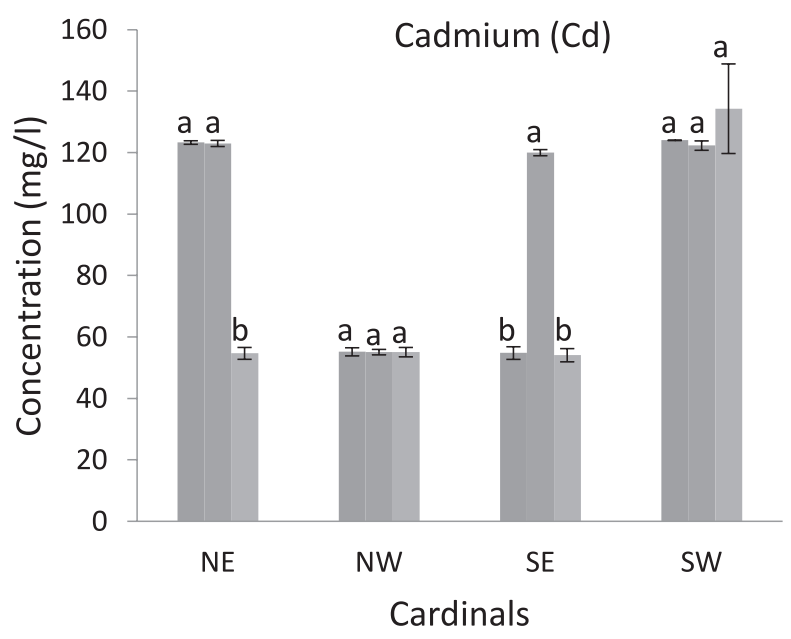

L. camara $\square$. maximum $\square$ D. stramonium

Fig. 2. Cadmium concentrations in plants collected from across the directions.

\section{Chromium (Cr)}

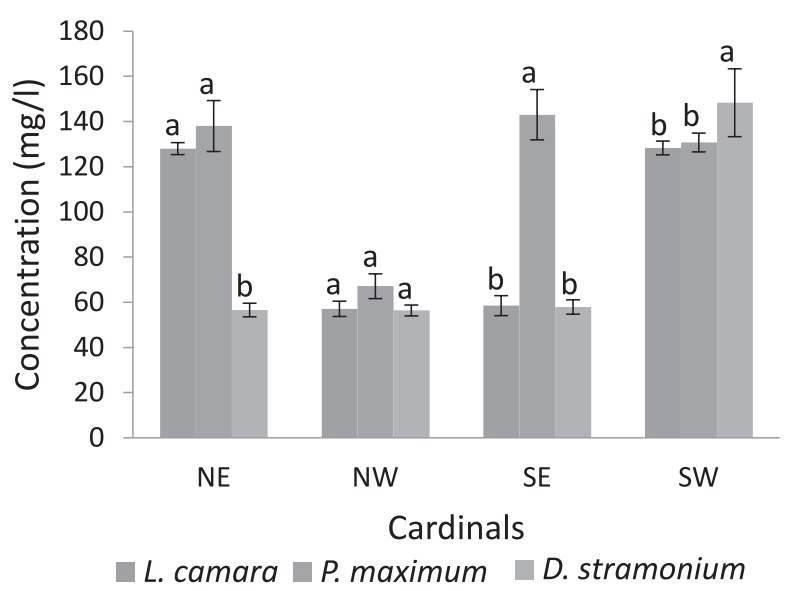

Fig. 3. Chromium concentrations in plants collected from across the directions.
Copper (Cu)

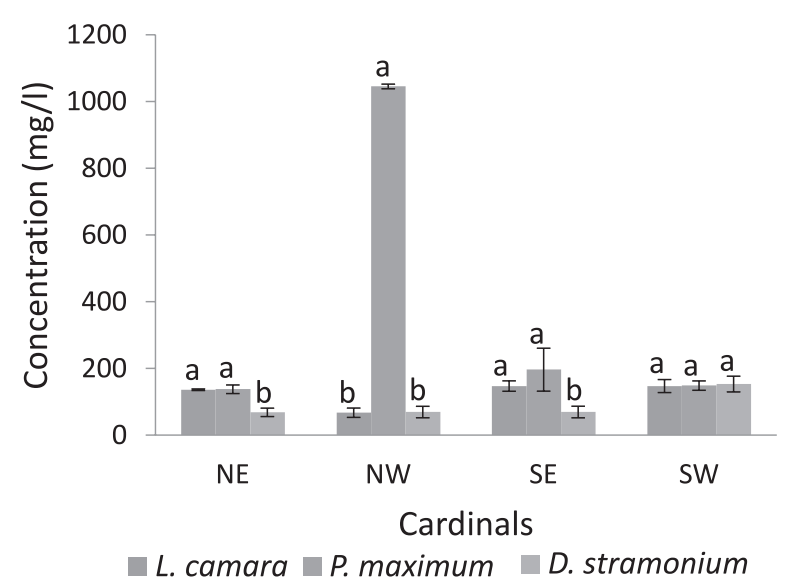

Fig. 4. Copper concentrations in plants collected from across the directions.

Zinc (Zn)

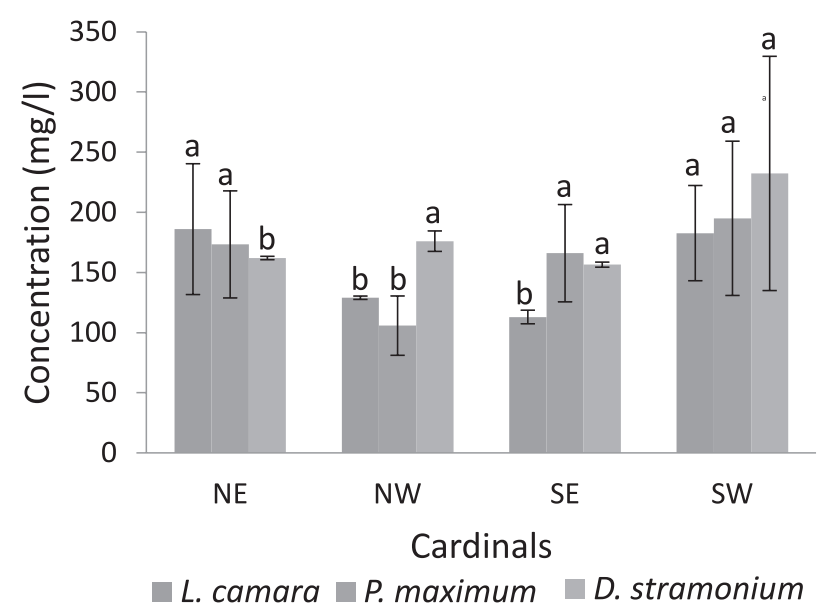

Fig. 5. Zinc concentrations in plants collected from across the directions.

in the southeast direction of the study site (Fig. 5). In addition, there is a significant difference $(p<0.05)$ in the concentration of $\mathrm{Zn}$ between $D$. stramonium and the other two plants (L. camara and P. maximum) in the northwest direction of the site (Fig. 5).

\section{Mercury (Hg)}

The concentration of $\mathrm{Hg}$ is significantly different $(\mathrm{p}<0.05)$ between $D$. stramonium and the other two plants (L. camara and P. maximum) at the northeast and the southwest directions of the site (Fig. 6). In the southeast direction of the study site, there is significant difference $(\mathrm{p}<0.05)$ in the concentration of $\mathrm{Hg}$ between P. maximum and the other two plants (L. camara and D. stramonium) (Fig. 6). There is no significant difference in the concentration of $\mathrm{Hg}$ between D. stramonium and P. maximum in the northwest direction of the study site (Fig. 6). 


\section{Mercury $(\mathrm{Hg})$}

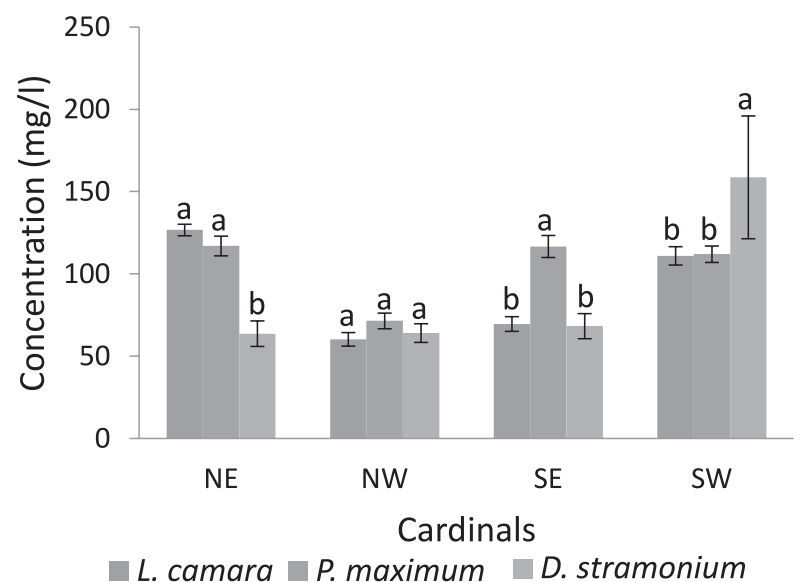

Fig. 6. Mercury concentrations in plants collected from across the directions.

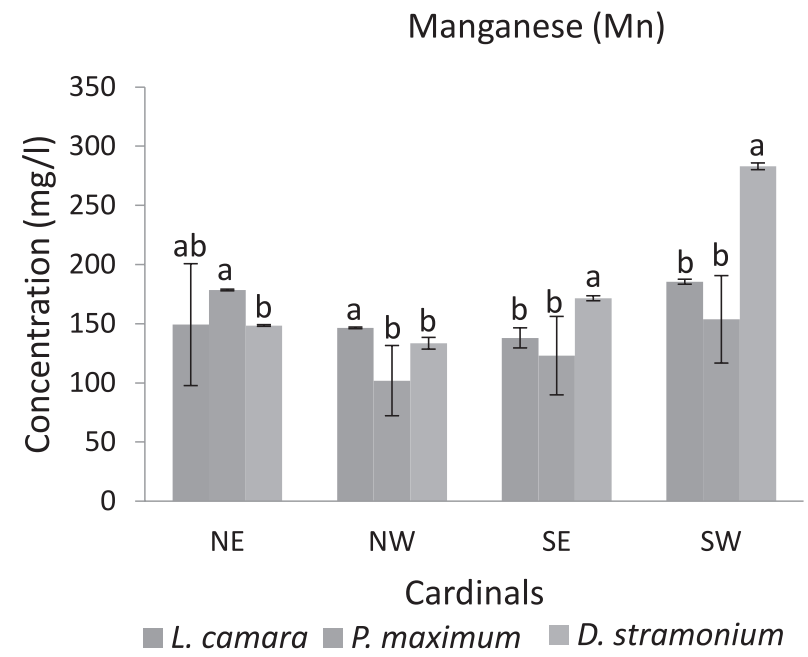

Fig. 7. Manganese concentrations in plants collected from across the directions.

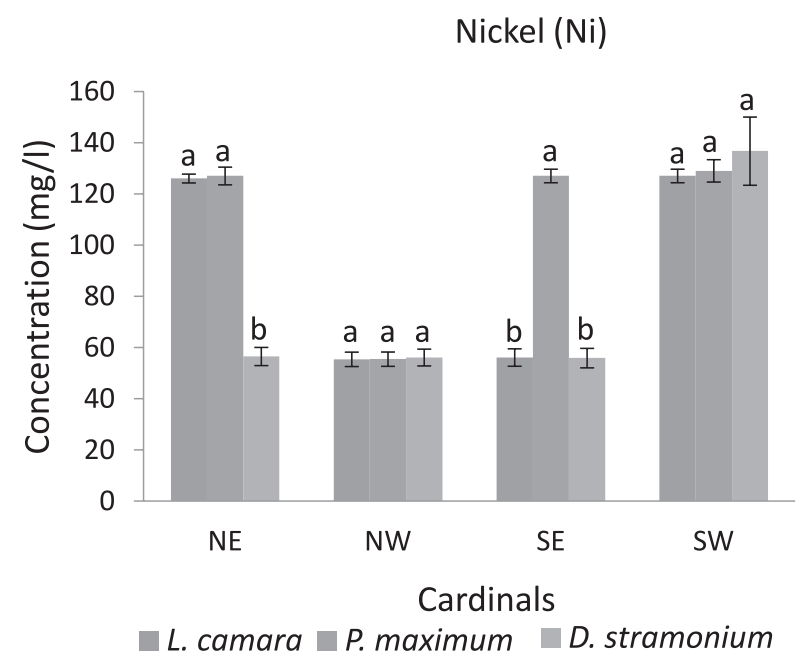

Fig. 8. Nickel concentrations in plants collected from across the directions.

\section{Manganese (Mn)}

There is significant difference $(\mathrm{p}<0.05)$ in the concentration of $\mathrm{Mn}$ between $D$. stramonium and the other two plants (L. camara and P. maximum) at the southeast and southwest directions of the study site (Fig. 7). In the northwest direction there is significant difference $(\mathrm{p}<0.05)$ between $L$. camara and the other two plants ( $P$. maximum and D. stramonium). There is significant difference $(\mathrm{p}<0.05)$ in $\mathrm{Mn}$ concentration between $D$. stramonium and $P$. maximum in the northeast direction of the study site.

\section{Nickel (Ni)}

In the northwest and the southwest direction of the study site there is no significant difference in the concentration of $\mathrm{Ni}$ among the three plants (Fig. 8). There is significant difference $(\mathrm{p}<0.05)$ in the concentration of Ni between $P$. maximum and the other two plants $(L$. camara and D. stramonium) in the southeast direction of the study site (Fig. 8). The concentration of $\mathrm{Ni}$ is significantly different $(\mathrm{p}<0.05)$ between $D$. stramonium and the other two plants (L. camara and P. maximum) in the northeast direction of the study site (Fig. 8).

\section{Discussion}

The negative impacts of elevated trace metals on vegetation and human health abounds in literature [5, 7]. Trace metals contamination and persistence in the environment and subsequent transfer through foodchain magnification is hazardous and results in grave consequences in plants and humans [21]. Several studies have reported that the extent of damage and absorption of these trace metals in plants differs and depend on factors such as sizes and shapes of the leaves, the nature of the leaves and stomata abundance of the leaves [23, 24]. For instance, $\mathrm{Cr}, \mathrm{Cd}$ and $\mathrm{Pb}$ at high concentrations are toxic to plants by altering the seedling germination process and hindering growth and development [25-27].

Trace metals such as $\mathrm{Cu}, \mathrm{Ni}$ and $\mathrm{Zn}$ are classified as essential elements for proper growth, morphology, and physiological well-being of plants; however, these trace metals are toxic at higher concentrations in plants [22]. Although $\mathrm{Ni}$ and $\mathrm{Zn}$ are essential elements at low concentration, increased $\mathrm{Ni}$ and $\mathrm{Zn}$ concentrations from different sources such as atmospheric deposition have hazardous effects on biota of plants throughout terrestrial food chains [28-30]. High $\mathrm{Cr}$ concentration causes a decrease in plant biomass and secondary metabolites such as sugars, chlorophyll, and carotenoids [31]. A similar development was found in Phyllanthus amarus and Brassica juncea for increased concentration of $\mathrm{Cd}[32]$.

In this present study, the concentrations of trace metals recorded from all directions showed values that were above the recommended limit as set for 
trace metals in plants [21]. The permissible limit set by the WHO for $\mathrm{Cd}$ in plants is $0.03 \mathrm{mg} / \mathrm{kg} \mathrm{d.m.,}$ $\mathrm{Cr}-0.05 \mathrm{mg} / \mathrm{kg}$ d.m., $\mathrm{Zn}-3.00 \mathrm{mg} / \mathrm{kg}$ d.m., $\mathrm{Hg}-0.5 \mathrm{mg} / \mathrm{kg}$ d.m., $\mathrm{Mn}-0.50 \mathrm{mg} / \mathrm{kg}$ d.m., $\mathrm{Ni}-0.02 \mathrm{mg} / \mathrm{kg}$ d.m., $\mathrm{Fe}-63.55 \mathrm{mg} / \mathrm{kg}$ d.m. and $\mathrm{Cu}-1.89 \mathrm{mg} / \mathrm{kg}$ d.m [21]. The plants (Pannicum maximum, Lantana camara, and Datura stramonium) in this study have been reported as forage plants [33] and trace metal monitoring plants, as well as phytomedicine $[34,35]$.

Fe has the highest concentration in all plants across all the wind directions (NE, NW, SE, and SW). This suggests other possible sources for $\mathrm{Fe}$ concentration aside the quarry site. A study in Pretoria reported a similar trend in the concentrations of $\mathrm{Fe}$ from a plant collected around a mining site that was attributed to its abundant elemental composition in plants [23, 36]. A high level of $\mathrm{Fe}$ in herbal/edible plants was reported from a study conducted in Pakistan and Nigeria [37, 38].

The high concentration of all trace metals in the southwest direction except in $\mathrm{Cu}$ could be due to the direction of the prevailing wind and position of the stack. In a study on the evaluation of the impact of limestone quarry on suspended and accumulated dust in northern Israel, mineralogical and chemical analyses of the dust samples indicated that wind direction plays a major and definite role on the amount of trace metals in dust particles analyzed as the prevailing wind direction impacted positively on the amount of dust particles which translated to an increase in trace metals [5]. Similarly, in a study in South Africa, wind direction was reported to have had a considerable impact on the presence and amount of trace metal deposition in Amaranthus spinosus collected around a coal-fired power plant [39]. Studies have shown that distance and prevailing wind have great effect on the deposition of trace metals and its amounts on plants around an industrialized region of South Africa [39-43].

Though the values obtained for all trace metals from all locations were not significantly different from one another, they are above the permissible limits as recommended by WHO. This might be a result of the effect of season and the time at which the samples were collected. Seasonal variations have been reported in literature to affect the deposition and levels of trace metals in plant parts [44]. The present study was carried out during the summer period and there might be a significant effect of rain in reducing the concentration of deposited trace metals in and on the leaves. The concentrations of $\mathrm{Cu}$ and $\mathrm{Pb}$ were low during the summer when compared to the winter period, and this phenomenon was attributed to the effect of rain and maturity during the summer and winter periods, respectively [44, 45].

From this study, there was a great variety in the structure and nature of the plant leaves which could have been responsible for the differences in the concentrations of trace metals in the foliage of the plants. The abilities of plants to absorb trace metals through the leaf stomata greatly varies and it is dependent on factors such as the size, nature, and shapes of the leaves, and the size and abundance of stomata in the leaves may affect the levels of trace metals in plants [24].

Pannicum maximum has simple alternate leaves and Lantana camara is quite rough, while Datura stramonium are large and angular. The findings of this study are in agreement with other studies where plants that were collected from a quarry vicinity exhibited trace metal values that were above the WHOrecommended limits $[46,47]$.

\section{Conclusion}

We discovered that the concentrations of all the trace metals $(\mathrm{Cu}, \mathrm{Cd}, \mathrm{Mn}, \mathrm{Hg}, \mathrm{Zn}, \mathrm{Fe}, \mathrm{Cr}$, and $\mathrm{Ni}$ ) were generally above the permissible limits set by WHO. Concentrations of toxic trace metals above the recommended limit in plants may be dangerous, considering the non-biodegradable nature of these toxic metals and the carcinogenic effect of some of these metals.

Though the differences obtained in the concentrations of the studied metals in leaves were not significant, the values obtained for Datura stramonium were higher than all other plants, and these may be due to the size of the leaves, which may favor the uptake of these metals via the leaf stomata.

Wind direction and the position of the stack might also have accounted for the presence of these trace metals form the Southwestern direction when compared with other directions where plant samples were collected in this study.

Due to high concentrations recorded for elements such as $\mathrm{Cd}, \mathrm{Cr}, \mathrm{Mn}, \mathrm{Hg}$, and Fe, it may be necessary to have a periodic monitoring program carried out around the quarry site in order to monitor the impact of the quarry site in releasing trace metals in the environment. Furthermore, due to the high concentrations of some toxic trace metals recorded in some plants collected around the site, prolonged consumption of these plants either by grazing animals (Pannicum maximum) or use for medicinal purposes (Datura stramonium) are strongly discouraged.

It is recommended that further studies may be carried out to determine the impact of the quarry on plant diversity and its impact on human health.

\section{Conflict of Interest}

The authors declare no conflict of interest.

\section{References}

1. STATISTICS SOUTH AFRICA. Gross domestic product. Statistical Release. P0441. 06 June 2017. 


\section{DEPARTMENT OF MINERAL RESOURCES.} Assessment of the broad-based socio-economic empowerment charter for the South African mining industry (Mining Charter). Republic of South Africa. May 2015.

3. TARRAS-WAHLBERG H., CRONJÉ F., REYNEKE S., SWEET S. Meeting local community needs: The cases of iron ore mining in Sweden and South Africa. The Extractive Industries and Society 4, 652, 2017.

4. LAMEED G.A., AYODELE A.E. Effect of quarrying activity on biodiversity. African Journal of Environmental Science and Technology 4 (11), 740, 2010.

5. BLUVSHTEIN N., MAHRER Y., SANDLER A., RYTWO G. Evaluating the impact of a limestone quarry on suspended and accumulated dust. Atmospheric Environment 45 (9), 1732, 2011.

6. CHARRON A., HARRISON R. Fine and coarse particulate matter on a heavily trafficked London highway: sources and processes. Environmental Science and Technology 39, 7768, 2005.

7. VENTER A.D., VAN ZYL P.G., BEUKES J.P., JOSIPOVIC M., HENDRIKS J., VAKKARI V., LAAKSO L. Atmospheric trace metals measured at a regional background site (Welgegund) in South Africa. Atmos. Chem. Phys. 17, 4251, 2017

8. THOMAS J., HARILAL B. Properties of cold bonded quarry dust coarse aggregates and its use in concrete. Cement \& Concrete Composites 62, 67, 2015.

9. NAN Y., LIU W.B., XIE H.T., GAO L.R., HAN Y., WANG M.J., LI H.F. Distribution and assessment of heavy metals in the surface sediment of Yellow River China. Journal of Environmental Science 39, 45, 2016

10. COBBINA S.J., CHEN Y., ZHOU Z., WU X., ZHAO T., ZHANG Z., FENG W., WANG W., LI Q., WU X. Toxicity assessment due to sub-chronic exposure to individual and mixtures of four toxic heavy metals. Journal of Hazardous Materials 294, 109, 2015.

11. LI F., HUANG J., ZENG G., YUAN X., LI X., LIANG J., WANG X., TANG X., BAI B. Spatial risk assessment and sources identification of heavy metals in surface sediments from the Dongfing Lake, Middle China. Journal of Geochemical Exploration 132, 75, 2013.

12. RAINBOW P.S., LUOMA S.N. Trace metals in aquatic invertebrates. In: Beyer, W.N., Meador, J.P. (Eds.), Environmental Contaminants in Biota: Interpreting Tissue Concentrations. Taylor and Francis Books, Boca Raton, FL, USA. 231, 2011.

13. QIU QIU Y., GUAN GUAN D., SONG SONG W., HUANG K. Capture of heavy metals and sulfur by foliar dust in urban Huizhou, Guangdong Province, China. Chemosphere 75 (4), 447, 2009.

14. NARTEY V.K., NANOR J.N., KLAKE R.K. Effects of quarry activities on some selected communities in the lower Manya Krobo District of the Eastern region of Ghana. Atmospheric and Climate Sciences 2, 362, 2012.

15. ANDREW M.F. The effects of dust on vegetation, A review. Environmental Pollution, 79, 63, 1993.

16. ADREES M., IBRAHIM M., MEHMOOD A., ABBAS F., SALEEM F., RIZWAN M., HINA S., JABEEN F., ALI S. Gaseous pollutants from brick kiln industry decreased the growth, photosynthesis, and yield of wheat (Triticum aestivum L.). Environmental Monitoring and Assessment 188, 1, 11, 2016

17. JAHAN S., FALAH S., ULLAH H., RAUF N. Antioxidant enzymes status and reproductive health of adult male workers exposed to brick kiln pollutants in Pakistan.
Environmental Science and Pollution Research 23, 12932 , 2016.

18. DRACK J.M.E., VAZQUEZ D.P. Morphological response of a Cactus to cement dust pollution. Ecotoxicology and Environmental Safety 148, 571, 2018.

19. CHAKRABORTY S., SOLANKI R., DAVE J., RANA S. KUMAR R.N., BHATTACHARYA T. Effect of airborne fly ash deposition on morphology and biochemical parameters of Medicago sativa L. and Brassica juncea. Research in Environment and Life Sciences 2, 13, 2009.

20. WILLIAMS V.L., WHITING M.J. A picture of health? Animal use and the Faraday traditional medicine market, South Africa. J Ethnopharmacol. 179, 265, 2016.

21. JEELANIA N., ZHUA Z., WANGA P., ZHANGA P., SONGA S., YUANA H., ANA S., LENGA X. Assessment of trace metal contamination and accumulation in sediment and plants of the Suoxu River, China. Aquatic Botany 140, 92, 2017.

22. WORLD HEALTH ORGANIZATION (WHO). Toxicological evaluation of certain food additives. Joint FAO/WHO Expert Committee on Food Additives. Food Additive Series No. 683. World Health Organization, Geneva, 2001.

23. OLOWOYO J.O., MUGIVHISA L.L., BUSA N.G. Trace metals in soil and plants around a cement factory in Pretoria, South Africa. Polish Journal of Environmental Studies 24 (5), 2087, 2015.

24. TOMASEVIC M., VUKMIROVIC Z., RAJSIC S., TASIC M. STEVANOVIC B. Characterization of trace metal particles deposited on some deciduous tree leaves in an urban area. Chemosphere, 61, 753, 2005.

25. LIU J.N., ZHOU Q.X., SUN T., MA L.Q., WANG S. Growth responses of three ornamental plants to $\mathrm{Cd}$ and $\mathrm{Cd}-\mathrm{Pb}$ stress and their metal accumulation characteristics. Journal of Hazardous Materials 151, 261, 2008.

26. SHANKER A.K., CERVANTES C., LOZA-TAVERA H., AVUDAINAYAGAM S. Chromium toxicity in plants. Environment International 31, 739, 2005.

27. ALI N.A., BERNAL M.P., ATER M. Tolerance and bioaccumulation of cadmium by Phragmites australis grown in the presence of elevated concentrations of cadmium, copper, and zinc. Aquatic Botany 80, 163, 2004.

28. GALL J.E., BOYD R.S., RAJAKARUNA N. Transfer of heavy metals through terrestrial food webs: a review. Environmental Monitoring and Assessment 187, 201, 2015.

29. GONNELLI C., RENELLA G. Chromium and Nickel. In: Alloway, B.J. (Ed.), Heavy Metals in Soils: trace metals and metalloids in soils and their bioavailability. Springer Netherlands, Dordrecht, 313, 2013.

30. MERTENS J., SMOLDERS E. Zinc. In: Alloway, B.J. (Ed.), Heavy Metals in Soils: trace metals and metalloids in soils and their bioavailability. Springer Netherlands, Dordrecht, 465, 2013.

31. RAI V., MEHROTRA S. Chromium-induced changes in ultramorphology and secondary metabolites of Phyllanthus amarus Schum \& Thonn. - anhepatoprotective plant. Environmental Monitoring and Assessment 147 (1-3), 307, 2008.

32. SHARMILA P., KUMARI P.K., SINGH K., PRASAD N.V.S.R.K., PARDHA-SARADHI P. Cadmium toxicityinduced proline accumulation is coupled to iron depletion. Protoplasma, 1, 2016.

33. FERNANDES F.D., RAMOS A.K.B., JANK L., CARVALHO M.A., MARTHA Jr. G.B., BRAGA G.J. Forage yield and nutritive value of Panicum maximum 
genotypes in Brazilian savannah. Scientia Agricola 71 (1), 23, 2013.

34. OLATUNJI O.S., XIMBA B.J., FATOKI O.S., OPEOLU B.O. Assessment of the phytoremediation potentials of Panicum maximum (guinea grass) for selected heavy metal removal from contaminated soil. African Journal of Biotechnology 2014. doi: 10.5897/AJB2014.13635.

35. TANCE F.B.G., ALBERT E. Air pollution tolerance indices of plants growing around Umuebulu Gas Flare Station in Rivers State, Nigeria. African Journal of Environmental Science and Technology 7, 1, 2013.

36. OLOWOYO J.O., VAN HEERDEN E., FISCHER J.L. Trace metals concentrations in soil from different sites in Pretoria, South Africa. Sustainable Environment Research 23 (2), 93, 2013.

37. PARVEEN R., ABBASI A.M., SHAHEEN N., SHAH M.H. Accumulation of selected metals in the fruits of medicinal plants grown in urban environment of Islamabad, Pakistan. Arabian Journal of Chemistry 2017. http://dx.doi.org/10.1016/j.arabjc.2017.04.010. In press.

38. AJASA A.M.O., BELLO M.O., IBRAHIM A.O., OGUNWANDE I.A., OLAWORE N.O. Heavy trace metals and macronutrients status in herbal plants of Nigeria. Food Chemistry 85, 67, 2004.

39. OLOWOYO J.O., XABA M.W. Concentrations of trace metals in Permalia sulcata transplanted around a coal fired power station in Pretoria, South Africa. Pollution Research 36 (1), 144, 2017

40. JAARS K., VAN ZYL P.G., BEUKES J.P., HELLEN H., VAKKARI V., JOSIPOVIC M., VENTER A.D., RASANEN M., KNOETZE L., CILLIERS D.P., SIEBERT S.J., KULMALA M., RINNE J., GUENTHER A., LAAKSO L., HAKOLA H. Measurements of biogenic volatile organic compounds at a grazed savannah grassland agricultural landscape in South Africa. Atmospheric Chemistry and Physics 16, 15665, 2016.

41. JAARS K., BEUKES J.P., VAN ZYL P.G., VENTER A.D., JOSIPOVIC M., PIENAAR J.J., VAKKARI V.,
AALTONEN H., LAAKSO H., KULMALA M., TIITTA P., GUENTHER A., HELLEN H., LAAKSO L., HAKOLA $\mathrm{H}$. Ambient aromatic hydrocarbon measurements at Welgegund, South Africa. Atmospheric Chemistry and Physics 14, 7075, 2014.

42. TIITTA P., VAKKARI V., CROTEAU P., BEUKES J.P., VAN ZYL P.G., JOSIPOVIC M., VENTER A.D., JAARS K., PIENAAR J.J., NG N.L., CANAGARATNA M R., JAYNE J.T., KERMINEN V.M., KOKKOLA H., KULMALA M., LAAKSONEN A., WORSNOP D.R., LAAKSO, L. Chemical composition, main sources and temporal variability of PM1 aerosols in southern African grassland. Atmos. Chem. Phys. 14, 1909, 2014.

43. VENTER A.D., VAKKARI V., BEUKES JP., VAN ZYL P.G., LAAKSO H., MABASO D., TIITTA P., JOSIPOVIC M., KULMALA M., PIENAAR J.J., LAAKSO L. An air quality assessment in the industrialized western Bushveld Igneous Complex, South Africa. S. AFR. J. SCI. 108, 1059, 2012.

44. SHAILAJAN S., SHAH S. Effect of seasonal variation on some heavy metal contents of a medicinal plant Swertia densiflora (Griscb.) kashyap using ICP-OES technique. Nature Environment and Pollution Technology 7 (4), 605, 2008.

45. SIUDEK P., FRANKOWSKI M. Atmospheric deposition of trace elements at urban and forest sites in central Poland - Insight into seasonal variability and sources. Atmospheric Research 198, 123, 2017.

46. BHARTI BHARTI, S.K., TRIVEDI TRIVEDI, A., KUMAR KUMAR N. Air pollution tolerance index of plants growing near an industrial site. Urban Climate 2017 [In press].

47. MUSTAPHA B.A., KUBMARAWA D., SHAGAL M.H., HAYATUDEEN A. Heavy metal profiles of medicinal plants found within the vicinity of quarry site in Demsa, Adamawa State, Nigeria. British Journal of Applied Science \& Technology 13 (1), 1, 2015. 
